\title{
Analysis of tourism facilities' distribution and its optimization based upon Ashworth-Tunbridge and Getz Models using GIS; case study: Semnan in historical silk route
}

\author{
Issa Ebrahimzadeh ${ }^{1}$, Marzie Daraei ${ }^{2, *}$ \\ ${ }^{1}$ Faculty of Geography and Environmental Planning, University of Sistan and Baluchestan, Zahedan, Iran \\ ${ }^{2}$ Young Researchers Club Member, Researcher in Geography and Urban-Tourism Planning, Zahedan Branch, Islamic Azad University, \\ Zahedan, Iran
}

\section{Email address:}

M_A_Daraei@yahoo.com (M. Daraei)

\section{To cite this article:}

Issa Ebrahimzadeh, Marzie Daraei. Analysis of Tourism Facilities' Distribution and its Optimization Based upon Ashworth-Tunbridge and Getz Models Using GIS; Case Study: Semnan in Historical Silk Route. Humanities and Social Sciences. Vol. 2, No. 3, 2014 , pp. $47-56$. doi: 10.11648/j.hss.20140203.11

\begin{abstract}
This paper highlights distribution of tourism facilities in Semnan and compares them based upon Ashworth, Tunbridge and Getz models. Data analyzed by SPSS and T-test shows that despite of the existing many historical and cultural attractions of the Semnan and its location in the path of ancient Silk Road and also modern Tehran-Mashhad railway, optimal use of existing functions are not performed, because of inappropriate distribution of resources and facilities. In this paper, we have investigated optimal locations of facilities using GIS. Necessary suggestions have been provided to attract more tourists and to improve Semnan tourism planning.
\end{abstract}

Keywords: Tourism Development, Optimal Locations, Accommodation Facilities, Catering Facilities, Semnan, GIS

\section{Introduction}

Tourism is one of the principal ways through which our 'world-views' are shaped. This results not only from our holidays but also from the way destinations are represented through travel reviews, travel programs and documentaries, travel brochures and guides, advertising and the way in which we exchange our holiday experiences[1].

Nowadays tourism is one of the most dynamic economic activities, which plays an important role in sustainable development. The tourism industry has many benefits of social, economic and cultural environment by combining and utilizing both internal and external resources [2].

Tourism is widely believed to be the most rapidly growing global industry, and UNWTO forecasts international arrivals to increase by $4 \%$ to $4.5 \%$ in 2014 , again above its long-term forecast of $+3.8 \%$ per year between 2010 and 2020[3].

According to the world trade organization (WTO), investment in the tourism sector in 2010 has income of more than 1,400 billion dollars equivalent to $6.10 \%$ of total international investments. Also, the number of worldwide tourists in 2010 was estimated to be approximately 940 million people that the growth was $7 \%$ while the net income was over 1550 billion dollars in the world. The number of tourists in 2020 is expected to reach about a billion and 600 million people [4].

Today, tourism development planners have to pay attention to all aspects of national, regional and international levels for the public and private companies. This industry is an integrated multitask system. Therefore, tourism attractions will not provide travel boom, but the conditions of transportation and accommodation facilities for tourists should also be provided. On the other hand, although tourist accommodation is not the main purpose of visiting, but without providing residential facilities it could not be desirable journey. Thus, the demand for accommodation is a derived demand of such visiting.

Providing accommodation facilities as a part of the hoteling includes tourism facilities as the most dynamic sectors. Since these facilities are effective factors for supporting tourism, therefore they should be considered very important. Resort centers are in shared action with 
agencies, attractions and tourism destination, which has an important role in increasing sustainability of tourism [5]. In addition, the location of these centers are the most essential factors in their success, and the exact location of these facilities should be appropriate and constructed in sites where to be available and comfortable for passengers. Besides, it is possible to be located near parks, intersection of main roads, airports, commercial and industrial facilities.

For a successful tourism development, proper infrastructure is essential and its existence and expansions are vital, particularly for the less developed countries and regions where often have limited infrastructure [6].

Semnan in the ancient silk route, like many other cities of Iran, is one of the places that known for its great historical and cultural tourism attractions, and holds desirable capacities to attract domestic and foreign tourists. One of the most basic and also necessary needs for this city is more developments of tourism infrastructures including modern accommodations and catering facilities. In this paper, to have analyses on the tourism improvement of Semnan city, we have investigated two important factors of tourism facilities, including accommodation and catering centers.

\section{Literature Review}

\subsection{Tourism Industry Concepts and Frameworks}

Tourism industry plays an important role in economic growth and also reveals the historical and cultural background of the places. The industry is very important in economic and social development, so it is known as "invisible exports" by economists [7]. The geographic information system (GIS), which has a computer based high capability of location finding, was introduced for the first time in the early 1960 in the Canada. After that it became a global and popular system in the 80s. Most developed countries have established comprehensive national GIS of their own, so they can provide invaluable data for public and private agencies and companies [8]. Several studies regarding usage of GIS have been conducted world widely. Many researchers e.g. Christodoulakis believes that this technology offers great opportunities for the development of modern tourism applications using maps to provide information to the users in a natural and effective way. One approach to provide GIS functionality in applications is to exploit the facilities offered by modern operating systems for interoperability [9]. Feng and Morrison have also mentioned the use of GIS to develop tourism and site location of medical centers [10]. The GIS is now adopted for managing, analyzing, and displaying geographically referenced information. Geographical information can be shown by a set of data. In other words, it could be include a comprehensive set of tools to work on the geographical data [11].

Many researchers have commented on the supply of tourism and its elements. With the supplied-centered perspective, Pearce D. J. considered tourism including attractions, transportation, accommodation, supportive facilities (such as travel agencies, banking, recreation, shopping, and insurance) and infrastructure [12]. Inskeep has considered six tourism factors including: attractions and activities, accommodation facilities, other tourism facilities and services, transportations, other infrastructure, and related institutional elements. Each of these elements could be described as follows:

○ Attractions and activities: natural, cultural, special types,

- Accommodation facilities: hotels, inns, hotel apartments,

o Other tourism facilities and services: trip and tour operations, catering facilities, shopping centres, banks and exchange offices, medical facilities and postal services,

- Transportation: aerial, road, rail, water,

o Other infrastructure: water and electricity supplies, waste disposal, telecommunications,

o Related institutional elements: organizational structures (public and private sectors), related tourism laws and regulations, training programs and services, funding to develop attractions, marketing and advertising strategies and trip organizational arrangements [12].

\subsection{Tourism Facilities}

Since every historical and touristic city requires equipped accommodation facilities, therefore one of the important needs of the tourism sector would be hotels and catering centres. Although, all tourists do not prefer using expensive hotels, so due to the diversity tastes, the city needs variant kind of hotels and catering centres. Tourists who use any kind of hotels have the most economic impacts in the tourism industry [13]. Also, other sections include catering services (such as restaurants, fast foods and snack shops) which could be categorized and graded by their size and location of restaurant, level and type of services, and etc. [14].

Scattering and spatial distribution of accommodation and catering centres across a city could have impacts on behaviour of tourists and increase or decrease of the services. Thus, tourists cost will be increased if distance between the accommodation and catering centres and tourist attractions are far away. It worth to mention that, using hotels has the greatest economic impact in the tourism industry, so that more than $60 \%$ of tourism costs are spent on hotels [15]. By the increase of side hotel services, investors and in overall tourism industry can earn extra income. Consequently, with accurate investment and proper location finding for accommodation centre can play an essential role in the urban tourism, so that it brings tourists satisfaction, increases travel demand, and also inject more income into the urban tourism industry. Some researchers in this field are: Ashworth G.J., Tunbridge J.E., Law C.M., Getz D., Pearce D.J., Wall G., Dudycha, Hutchinson, Timothy D. and Smith S.L.J.[5].

\subsection{The Getz, Ashworth and Tunbridge Models}

Getz proposed the expression of "tourism business district" (TBD) based on his studies in Nigeria waterfall, New York and Ontario, that one part of the city with major 
attractions for visiting and services together will make "central business district" (CBD). Getz defined every section in his model that underscores: in the attraction section, the main attractions such as natural, historical and cultural; in the central business section, such as offices, retail businesses, department stores; in the services sector, such as transportation and internal access [5].

Smith (1985) discovered a number of spatial regularities for different types of restaurants in urban areas, which may be useful in assessing their effective locations. In the case of Toronto, Dudycha and Hutchinson (1985) found that the "hotel and motel" industry has become more concentrated in the CBD and along major transportation links, like as airport strip, instead of being more widely dispersed. In Christchurch, New Zealand, Pearce (1987) found that many of the city's hotels are clustered near the centre of the city, but many of the newer ones have been built in a linear style along the main highway axes. He recommended that the existing fewer small motels which located in the city core because of being unable to bear the high cost of central city rents [16].

The "tourist-historic city" as defined by Ashworth and Tunbridge (1990), is an area of overlap between a historic city and a city with various tourist functions [16]. They have proposed and indicated a typology of touristic used hotels locations and similar type clustering for classification of commercial accommodation establishments in historic cities, illustrated in the Figure1[17].

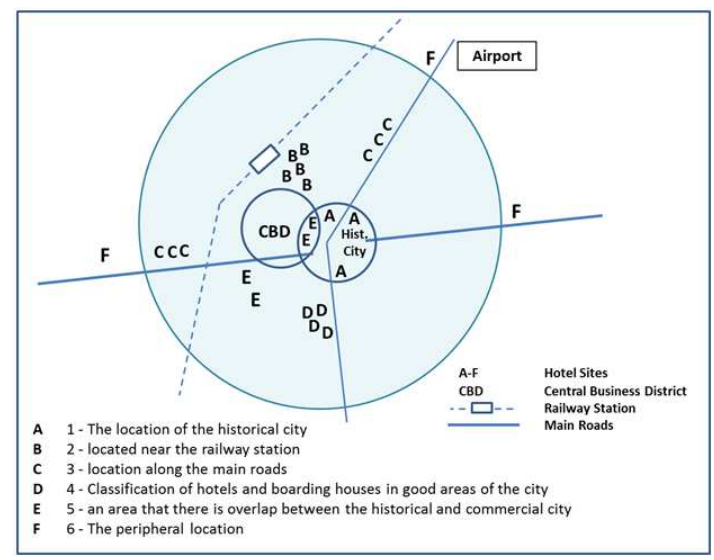

Figure 1. Typology of urban hotel locations [17]

As regard to a historic city, the model shows six types of hotel locations as follows: A- historical city locations, Brailway station locations, $\mathrm{C}$ - along main access roads, Dclusters of small hotels and pensions in nice areas, E- the zone of overlap between the historic and the modern commercial city, and F- peripheral locations. They explain that in summary, " $\mathrm{A}$ " hotels having likely operated continuously during centuries and many of the older ones are themselves considered a part of the historic city. The development of " $\mathrm{B}$ " and " $\mathrm{C}$ " locations can be seen as improvements in urban accessibility and " $D$ " sites exist as a result of convenient and attractive locations in or near high amenity zones. The hotels in "E" are within walking distance of both historic and modern attractions. Lastly, "F" hotels are bordering to the historic city, so that their construction causes a spatial separation of accommodation from other urban tourism resources, including heritage. These hotels are conveniently located for tourists desiring to visit more attractions outside the urban area than the historic core of a city [16].

\subsection{Silk Route}

The Silk Road, or Silk Route, (Figure 2) is a series of trade and cultural transmission routes that were central to cultural interaction through regions of the Asian continent connecting the West and East by linking traders, merchants, pilgrims, monks, soldiers, nomads and urban dwellers, from China to the Mediterranean Sea, during various periods of time [18].

Trade on the Silk Road was a significant factor in the development of the civilizations of China, the Indian subcontinent, Persia, Europe and Arabia. It opened long-distance, political and economic interactions between the civilizations [19].

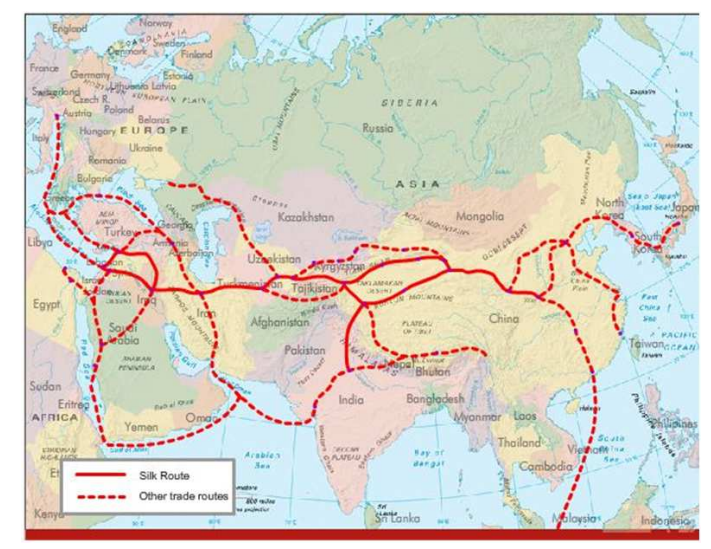

Figure 2. Silk Route [19]

Semnan is one of the provinces which have many historical and cultural tourist attractions to attract domestic and foreign tourists and have many desired capacities. But, according to authors' findings, these capacities have not been properly used so far. Thus, many tourist attractions in Semnan have remained unknown for domestic and foreign tourists [21].

In this paper, we try to answer the question: do the distribution of accommodations and catering centres in Semnan are performed in optimal situation, according to the models?

\section{Research Methodology}

In this paper, the research is performed based upon descriptive-analytical approach and it is a practical-aimed research. Field studies as well as documentary and library studies have been used to collect required information and data respectively. In this regard, two types of questionnaires based on Likert scale have been provided and asked from 
residents of Semnan and the tourists as well. In the descriptive-analytical method, the data were analysed by SPSS software via descriptive and inferential statistics, such as the "one sample T-test". The needed spatial information for mapping was obtained from "Iranian Organization of Surveying", with scales of 1:25000 and 1:50000. Also, Semnan land-use map obtained from "Semnan road and urban development department", and authors' field studies as well. In this regards, the ground reference of the available maps was digitized using ArcGIS software, and then data layers needed in our research were performed by updating the field studies. Finally, best sites to create or omit residential and catering centres for tourism development in Semnan were suggested via the software tools. Additionally, according to the suggested distribution, spatial distributions of catering and residential centres were analysed based on location, type, importance and role. Then, the results were compared the conventional models such as Ashworth and Tunbridge.

According to the Cochran formula, equation (1), a sample size of 383 citizens should be considered.

$$
n=\frac{\frac{t^{2} p q}{d^{2}}}{1+\frac{1}{N}\left[\frac{t^{2} p q}{d^{2}}-1\right]}
$$

where, $t$ is abscissa of the normal curve; estimated proportion that one is trying to estimate in the population $(p=0.5)$; degree of accuracy desired, assumed to be half the confidence interval $(\mathrm{d}=0.05)$; the probability of type I error (alpha). Population size $=\mathrm{N}$

Result of calculation based on estimated population size of 130000 is $~ 383$ :

$$
n=\frac{\frac{(1.96)^{2} * 0.5 * 0.5}{0.05^{2}}}{1+\frac{1}{130000}\left[\frac{(1.96)^{2} * 0.5 * 0.5}{0.05^{2}}-1\right]}=383.031
$$

Due to the lack of clarity of the exact population size, 500 questionnaires (instead of 383) were distributed among the citizens, and 420 questionnaires were considered after removing incomplete questionnaires to satisfy the $n$ calculated by the formula.

For individual tourists, sample size of 200 was selected. From the 200 collected questionnaires, only 100 questionnaires were totally completed and acceptable. The "validity" of the questionnaires in this research were assessed and confirmed by professors, advisors and other experts in the field of tourism. The calculated "reliability" of the questionnaires by selecting the desired components was
0.901, using Cronbach's alpha method and SPSS software, which indicates very good reliability.

\section{Objectives}

In this study, the core objective is that to locate the optimal touristic usages in Semnan, in order to make planning to attract more tourists to the Semnan city. Then the secondary objective is to helping the city's economic growth by identifying tourist attractions and locating the facilities for the same purpose.

So, to reach the objectives, the current tourist facilities have been identified, which is based on Ashworth and Tunbridge model. As it mentioned before, they are not well distributed in tourism attractions area.

\section{Research Findings}

\subsection{Area of Study}

Semnan city is capital of Semnan province with area of 2,446 hectares. The city is geographically located at $49^{\circ} 36^{\circ}$ of east longitude and $37^{\circ} 16^{\prime}$ north latitude, with average height of 1460 meters above sea level (Figure 3).

Semnan city with an area of $20,239 \mathrm{Km}^{2}$ is situated on the southern slopes of the Alborz Chain Mountains.

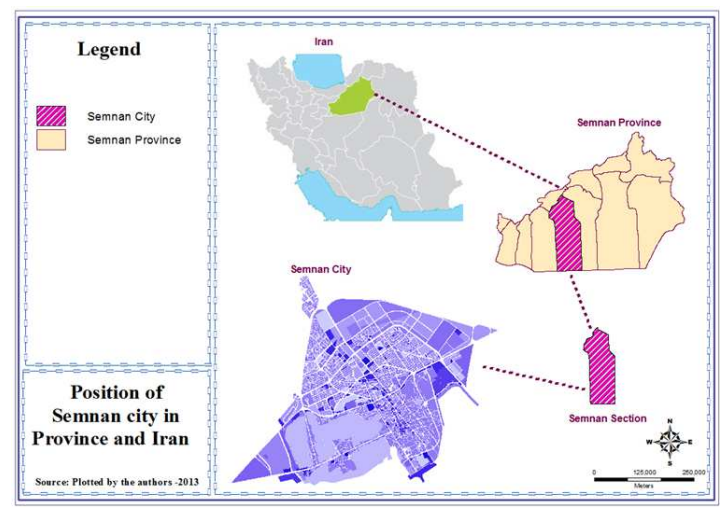

Figure 3. Position of Semnan city in the province and country

\subsection{Semnan Tourism Perspective}

Semnan province with more than 729 kinds of natural, historical-cultural and manmade attractions is considered as one of the region's potential for tourism in Iran. As illustrated in Table 1, 30.8\% of total attractions of the province are located in the Semnan city, and the rest are distributed in other major cities.

\begin{tabular}{|c|c|c|c|c|c|c|c|c|}
\hline \multirow{2}{*}{ Cities } & \multicolumn{2}{|c|}{ Total } & \multicolumn{2}{|c|}{ Natural } & \multicolumn{2}{|c|}{ Cultural-Hist. } & \multicolumn{2}{|c|}{ Man made } \\
\hline & No. & $\%$ & No. & $\%$ & No. & $\%$ & No. & $\%$ \\
\hline Semnan & 225 & 30.86 & 7 & 10 & 139 & 38.3 & 79 & 26.6 \\
\hline Shahroud & 215 & 29.4 & 27 & 39 & 84 & 23.2 & 104 & 35.1 \\
\hline Dameqan & 162 & 22.2 & 27 & 39 & 71 & 19.6 & 64 & 21.5 \\
\hline Garmsar & 127 & 17.6 & 9 & 12 & 68 & 18.9 & 50 & 16.8 \\
\hline Total & 729 & 100 & 70 & 100 & 362 & 100 & 297 & 100 \\
\hline
\end{tabular}

Table 1. Distribution of tourist attractions in Semnan province, classified by major cities [22] 
With 225 tourist attractions (139 cases are cultural-historical), and being located in the historical silk routes and the modern railway transit of Tehran-Mashhad, Semnan is one of the important historical and tourism cities that could play an essential role in the country's tourism industry [22].

In terms of attractions performance, not only have provincial importance, which has well weight nationally, but also have international levels too. In the city of Semnan there are 3 national and 1 international attraction in terms of performance (see Figure 4).

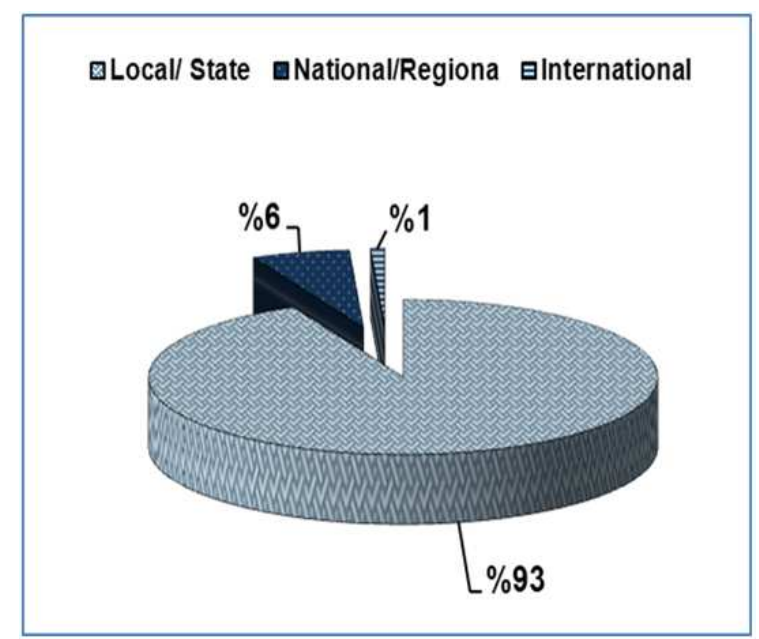

Figure 4. Tourist attractions in Semnan city, in terms of performance [ibid]

In historic cities such as Semnan, most attractions are ancient-historic and cultural. As we can see in the Figure 5, nine more important attractions are as follows: the market (Bazaar), Cisterns (water reservoirs), Grand Mosque, Imam Mosque and Citadel gate.

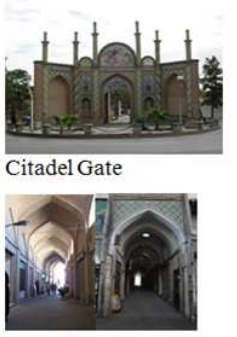

Old Market (Bazaar)

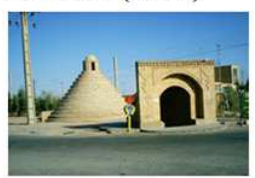

Cisterns (water reservoirs)

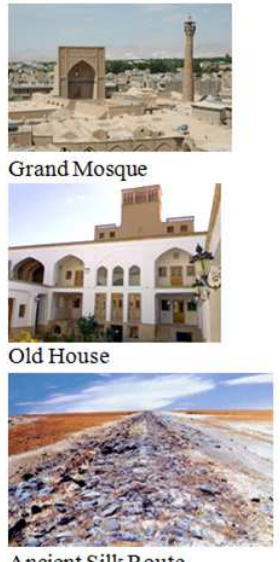

Ancient Silk Route

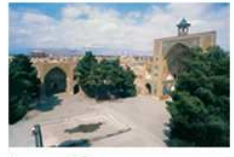

Imam Mosque

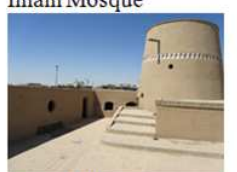

Water Mill

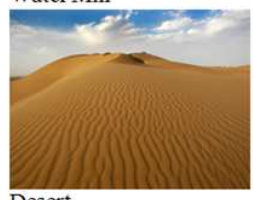

Desert
Figure 5. Some of the attractions in the Semnan city

In fact, almost $90 \%$ of the city's tourist attractions are located in the downtown and CBD center as depicted in the Figure 6.

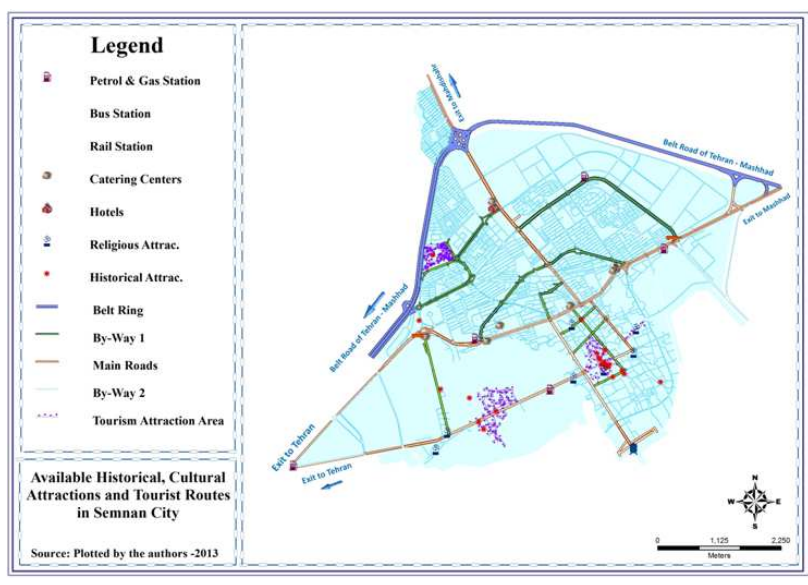

Figure 6. The city's tourist attractions and its

Spatial distribution of tourist attractions and also current residential and catering canters in the Semnan city are shown in Figure 7.

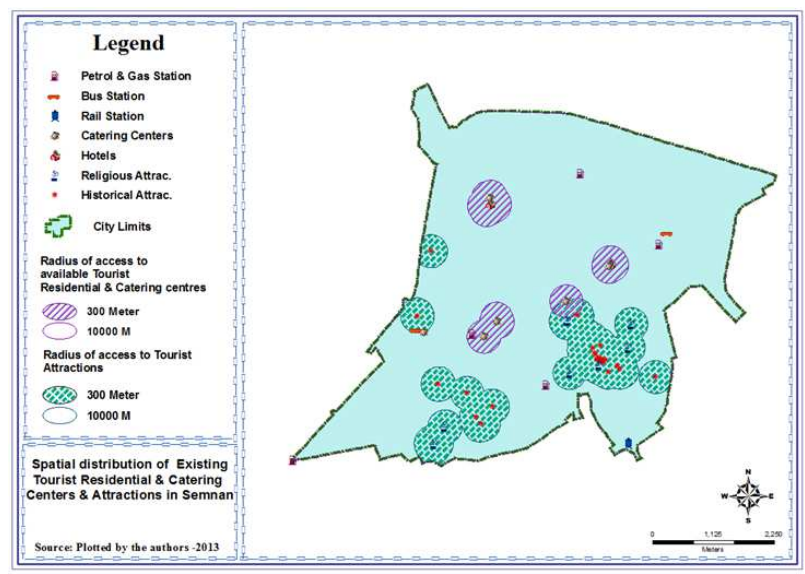

Figure 7. Spatial distribution of current residential and catering centres and tourist attractions in Semnan

\section{Data and Analyzing}

\subsection{Data}

According to the information from the "department of cultural heritage, handicrafts and tourism of Semnan" in 2012, number of 9003415 domestic tourists have been visited the province as passing visitors, and 3935 foreign tourists who stayed in hotels in the city, while the largest number of tourists entered was for the year 2011(12717000). In addition, the statistics obtained from "Iranian new year accommodation center" that is carried out by the directorate of cultural heritage, is described in the Table 2.

Despite the large number of tourism attractions as well as many tourists passing through, tourists do not stay long enough in Semnan, though possibly this is due to lack of sufficient and appropriate facilities. According to the statistics and direct authors' interviews with officials involved in this issue, it apparently seems that there are not 
satisfactory and enough welfare facilities and accommodations. Statistics also confirm the fact that Semnan city, with west-east transit passage situations which is commuting million passengers per year, have only two active hotels. It should mentioned, one of the main factors for the development of tourism in a city is enticing tourists to stay longer in the city, which requires to build and construct of more hotels and guest houses. The current active resources in the province are shown in the Table 3. Also, number of tourists who stayed in residential canters in 2012 (March-Sept) has also been presented in Table 4, that shows not satisfactory values.

Table 2. Number of tourists entered to the province in 2011 and Iranian New Year 2012 (21 March)

\begin{tabular}{llcc}
\hline Description & Accommodation Centers & $\mathbf{2 0 1 1}$ & $\mathbf{2 0 1 2}$ \\
\hline \multirow{2}{*}{ Acc. travellers' of New Year } & Education Dept. & 65324 & 99965 \\
& Cultural Heritage Resorts & 106716 & 93159 \\
The total acc. & Education \& Cultural Heritage Resorts & 172040 & 53.02 \\
Entering to the province & - & 2637050 & -12.70 \\
Visits to historical canters, & Fountain Ali Damghan & 27148 & 3151748 \\
recreation and tourism of the & Cultural historical Complex of Bastaam & 28235 & 92861 \\
province & Tomb of Sheikh Abolhassan Kharqany & 27935 & 35227 \\
Total visits & - & 83318 & 30923 \\
\hline
\end{tabular}

Source: Field survey findings, plus extra information obtained from the "department of cultural heritage, handicrafts and tourism in Semnan", 2012

Table 3. Number of tourist facilities in Semnan province, classified by cities - 2012

\begin{tabular}{lccccc}
\hline & Hotels & Inn & $\begin{array}{c}\text { Pensions } \\
\text { (Boarding House) }\end{array}$ & $\begin{array}{c}\text { Traditional } \\
\text { Restaurants }\end{array}$ & Motels \\
Agencies
\end{tabular}

Table 4. Number of travellers entered to the public resorts in Semnan, March-Sept. 2012

\begin{tabular}{|c|c|c|c|c|c|c|c|c|c|c|}
\hline \multirow{3}{*}{ Residential Centre } & \multicolumn{10}{|c|}{ Number of passengers entered into the resorts } \\
\hline & \multicolumn{2}{|c|}{ March-April } & \multicolumn{2}{|c|}{ April-May } & \multicolumn{2}{|c|}{ May-June } & \multicolumn{2}{|c|}{ June-July } & \multicolumn{2}{|c|}{ July-August } \\
\hline & $I^{*}$ & $F^{* *}$ & I & $\mathbf{F}$ & I & $\mathbf{F}$ & $\mathbf{I}$ & $\mathbf{F}$ & $\mathbf{I}$ & $\mathbf{F}$ \\
\hline Tourism Hotel of Semnan & 1073 & 15 & 830 & 14 & 721 & 13 & 895 & 17 & 681 & 17 \\
\hline Ghods Hotel & 498 & 2 & 507 & 8 & 423 & 0 & 454 & 2 & 360 & 0 \\
\hline Charfasl Inn & 0 & 0 & 0 & 0 & 0 & 0 & 0 & 0 & 0 & 0 \\
\hline Komesh Inn & 0 & 0 & 0 & 0 & 0 & 0 & 0 & 0 & 0 & 0 \\
\hline Boarding Houses & 1194 & 0 & 1194 & 0 & 1194 & 0 & 0 & 0 & 0 & 0 \\
\hline
\end{tabular}

* Iranian tourists **Foreign tourists

\subsection{Descriptive Analyses}

In order to gaining knowledge about the main views and motivations of tourists who travelling to the city of Semnan and also getting opinions of citizens regarding the appropriate distribution of existing tourism related resources facilities, the questionnaires were distributed and then the collected answer sheets have been analysed by using descriptive-analytical study.

Statistics of collected data from citizens show that the gender of $324(77.1 \%)$ are men and $96(22.9 \%)$ female out of 420 , and most of them were married. Also, the age range of respondents was between 21 to 45 years old and majority of them were educated to diploma and bachelor, plus most of them have been office employed.
Study about the gender of tourists, indicated that from the total number of 100 questionnaires, $63 \%$ were male and $37 \%$ female, with age distribution between 21-45 years old, and their education qualification were the same as citizens. They were most employed in offices and business sections. Tourists sample in this study have been travelled mostly with their families and used their own vehicles. Most tourists who entered to Semnan were passing through the city (33\%), because Semnan as it mentioned before is located in the route of Tehran-Mashhad. Statistics also shows that most passengers who going to Semnan normally travel in New Year holiday time $(21 \mathrm{March})$ and the months after (April and May). Figure 8 shows the origin cities of tourist who travelled to the city. 


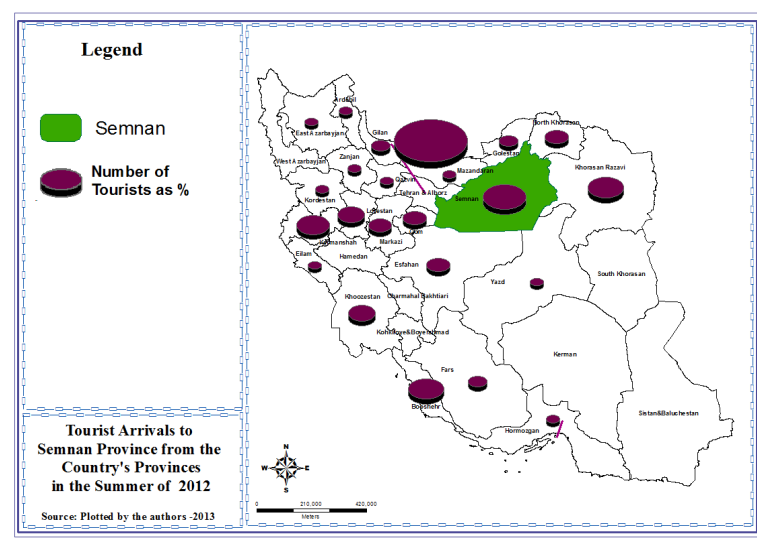

Figure 8. Tourist's origin city that travelled to Semnan

Some of the questions have been asked from citizens of Semnan and also tourists who have visited the city are as follows:

- What do you think of the quality and quantity of the hotels in Semnan, to accommodate tourists who travel to city?

- What is your opinion about the quantity and quality of catering centres (restaurants, fast foods and etc.) in the city for tourists who travel to Semnan?

- Are the number of hotels and other accommodation centres in Semnan enough, and their quality are suitable for tourists?

- What do you think about quality of catering centres (restaurants, fast foods and etc.) in the city for tourists?

- How are the conditions of access to the tourist attraction in Semnan, in your opinion?

\subsection{Inferential Analyses}

To analyse research findings to approach the objectives, considering the descriptive findings, statistical methods and "one sample T-test" were applied. Then, to prove that by using GIS software, the best locations for accommodations and catering centres were identified in the range of attractions. So, based on the objectives, two groups including citizens (420 people) and tourists (100 people) who entered or stayed in the hotels in the summer of 2012 (July-Sept.) were observed.

The hypotheses of $\mathrm{H}_{0}$ and $\mathrm{H}_{1}$ can be expressed as follows: $H_{0}: \mu \leq 3, H_{1}: \mu \geq 3$

$\mathrm{H}_{0}$ : The current distribution of tourist accommodation and catering centres within the area of attractions is not appropriate.

$\mathrm{H}_{1}$ : The current distribution of tourist accommodation and catering centres within the area of attractions is appropriate.

The results obtained separately from both groups (citizens and tourists) are shown in the Tables 5 and 6 . Considering the test value $=3$ and inferential statistics with confidence level of $95 \%$, proves that the components of accommodation and catering facilities with significant levels lower than alpha 0.05 (Sig=0.000) and negative upper and lower components, the mean value of test cases are smaller than 3 . Thus, $\mathrm{H}_{1}$ 'the current distribution of tourist accommodation and catering centres within the area of attractions' is rejected and on the other hand $\mathrm{H}_{0}$ is accepted (Tables 5 and 6).

Table 5. Significant level test for current distribution of tourism amenities and facilities from citizens respond, using the one sample T-test

\begin{tabular}{|c|c|c|c|c|c|c|}
\hline \multicolumn{7}{|c|}{ Test Value $=3$} \\
\hline & \multirow[t]{2}{*}{$\mathbf{N}$} & \multirow[t]{2}{*}{ df } & \multirow[t]{2}{*}{ Sig. (2-tailed) } & \multirow[t]{2}{*}{ Mean Difference } & \multicolumn{2}{|c|}{$\begin{array}{c}\mathbf{9 5 \%} \text { Confidence Interval of the } \\
\text { Difference }\end{array}$} \\
\hline & & & & & Upper & Lower \\
\hline Catering Centre & 420 & 419 & 0.00 & 2.20 & -0.71 & -0.89 \\
\hline Residential canters & 420 & 419 & 0.00 & 2.15 & -0.77 & -0.93 \\
\hline
\end{tabular}

Table 6. Significant level test for current distribution of tourism amenities and facilities from tourists respond, using the one sample T-test

\begin{tabular}{|c|c|c|c|c|c|c|}
\hline \multicolumn{7}{|c|}{ Test Value $=\mathbf{3}$} \\
\hline & \multirow{2}{*}{$\mathbf{N}$} & \multirow{2}{*}{ df } & \multirow{2}{*}{ Sig. (2-tailed) } & \multirow{2}{*}{ Mean Difference } & \multicolumn{2}{|c|}{ 95\% Confidence Interval of the Difference } \\
\hline & & & & & Upper & Lower \\
\hline Catering Centre & 100 & 99 & 0.023 & 2.77 & -0.43 & -0.03 \\
\hline Residential centers & 100 & 99 & 0.016 & 2.76 & -0.43 & -0.05 \\
\hline
\end{tabular}

By using GIS, according to the analyses of questionnaires, maps have been drawn for the new suggested locations of catering and residential canters in Semnan. For this purpose, to obtain the current status, land use map was optimized and categorized in GIS and then available residential and catering centers that were in certain layers have been buffered and then raster and finally were reclassified. To prepare new locations, weight of land-use map has been classified by using AHP and Fuzzy logic methods. Then, by using ultimate computational steps, correlation or overlap analyses have been performed on the data layers. Ultimately, the desired and optimized status maps were drawn for both tourist residential and catering canters separately in the range of attractions in the city (Figures 9).

According to the Figure 9, places with red color in routes where can be more accessible to the attractions, are 
identified as best places and the blue color places are the current routes or not appropriate for gain access to the attractions. Furthermore, as regard of residential and catering centers, the optimized places in the Semnan city are shown as the dark green, which in near the tourist attractions could be finding, CBD center and the incoming roads to the city as well.

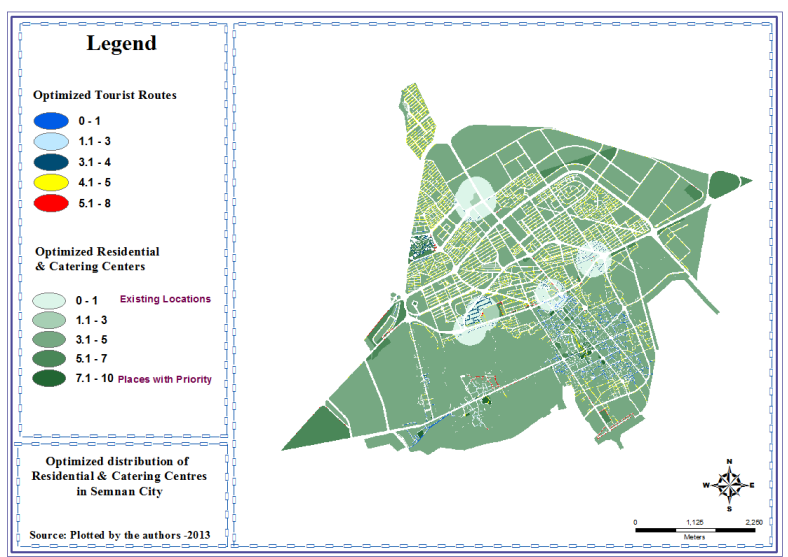

Figure 9. Optimized distribution of residential and catering centers for tourism planning in Semnan

\section{Further Investigation on the Status of Tourism in Semnan City Based on Reviewing Ashworth-Tunbridge and Getz Models}

Considering the spatial distribution of tourist attractions in Semnan (Figure 7), we decided to compare it with the Ashworth-Tunbridge and Getz models. Distribution of current accommodation and catering facilities in Semnan show that they are located in highways and main routes in the city, which somehow could be weakness due to lack of easy access to tourist attractions. Thus, location and distribution of the current hotels and catering centres are not well-matched with tourism attractions in historic city such as Semnan. In other words, correlation of three divisions of attractions, accommodation and catering centres with CBD in the city's historical range are not consistent with the model proposed by Getz. As Figures 6 and 7 shows, main highways and entrance and exit routes to the city have dominant role in locating of hotels and catering centres than the attraction areas.

As it has been well described in Timothy's article [16], the short average length of stay in Semnan (sometimes less than a day) defines it as a secondary rather than a primary destination for tourists.

\section{Discussions and Conclusions}

From the perspective view of tourism, geographically Semnan is located nearby the important metropolitan cities such as capital Tehran, Mashhad, Isfahan and north region cities. Also, being located in the modern transportation transit route as well as ancient 'Silk Road' route, it would provide opportunities required for the tourism development. On the other hand, climatic diversities (not explained here) provide extra opportunities for expansion of natural tourist attractions. Cold weather and environmental mountainous conditions in the north of the province accompanied by warm and dry conditions in the south with desert related attractions are other important components of eco-tourism in Semnan too.

In this paper, Semnan city has been studied based upon descriptive-analytical approaches accompanied by authors filed studies. In the descriptive-analytical approach, two types of questionnaires based on Likert scale were analysed by SPSS software via descriptive and inferential statistics, such as the "one sample T-test". Then, by using ArcGIS software, the best sites for residential and catering centres based on location, type, importance and role for tourism development in Semnan were suggested. Results were assessed and compared with the conventional models such as Ashworth and Tunbridge.

Our studies show that attractions, business and the historical parts in Semnan, where located in the central area could make the city more important and attractive for the national and international tourism after applying the suggestions. Currently, most of the tourist's accommodation and catering facilities are located in the highways and main routes, so that tourists and visitors have not very easy access to the city's historical attractions. Although, some researchers believe that localizing facilities and accommodation centres in downtown make traffic jam and crowd, but in the case of Semnan that attractions are mostly located in the city centre, so we have to find a solution to make the attractions accessible for tourists. The CBD of Semnan, especially its historical related market (Bazaar) is not only located in the city centre, but also is part of heritage site of urban attraction, so by managing tourism affairs, it could play a significant role in attracting more tourism to the city.

The current distribution of few hotels and catering centres in Semnan are located in the main roads that are consistent with the Ashworth and Tunbridge model. Although, present research indicated the spatial distribution of tourist's amenities in Semnan are away from city centre, which could be a disadvantage, because tourists and travellers just pass through the city without visiting the attractions. To solve this kind of problem, we suggest that the municipality of Semnan city need to lead travellers into the city instead of passing through beltway roads. Moreover, it should be more advertising about the attractions, by publishing some leaflets and CDs about the attractions to the tourists passing from Semnan and also establishing big billboards and electronic displays.

Furthermore, findings of this study indicate that Semnan is not a successful city in attracting tourism, because of mainly lack of proper facilities, infrastructure and tourism services and weakness of resources management. In addition, inappropriate distribution of amenities, plus very low advertisements (causing less general awareness about attractions and potentials of tourism), makes the problem more complicated. As it is explained, according to the Getz 
model, the short average length of stay in Semnan, defines it as a secondary rather than a primary destination.

To resolve the problem stated in this paper, one of the core objective was to locate the optimal touristic usages in Semnan, in order to attract more tourists to the city based on optimized tourism planning. Then the secondary objective was to help the city's economic growth by identifying tourism attractions and locating the facilities for attracting more tourists to the city. So, to achieve the objectives, the current tourist facilities have been identified, which are based on Ashworth and Tunbridge model as it is explained in the context. Finally, to gain better results, proper and optimized places and distribution of new facilities have been suggested by using GIS software.

\section{Suggestions and Strategies}

For further tourism development in Semnan based on the analysis of research, the following activities and strategies are suggested:

- Proper distribution of tourism infrastructure such as hotels, guesthouses, restaurants, bars, recreation areas and cultural centers within the city of Semnan, and monitoring their performance;

- Improving the quality level of tourism products, such as: accommodation canters, catering canters, travel agencies, and tour guiding and transportation networks;

- Activating the travel agencies for organized day-trips tours to attract tourists and familiarize them and residents with various city attractions;

- By installing the large digital displays in the parks and playing back images and documentary programs about city's attraction and culture, to encourage tourists to visit places. This could be very effective in restaurants, hotels and other related facilities;

- Build more traditional restaurants, to introduce Semnan's foods, culture and customs to tourists who are interested in this concept;

- Holding permanent and seasonal exhibitions and festivals in the area of attractions as well as in bus stations and railway terminals, to introduce the various city attractions, handicrafts and customs to the citizens and tourists;

- Moreover, the findings indicate that standardize of strategies based on optimal distribution infrastructure in the city, can be effective in tourism development of Semnan. In addition, according to the planners of this industry, we can reduce the problem of seasonality of tourism demand in all the cities of province. Furthermore, it provides satisfaction of tourists and increases their length of stay in the province and ultimately increases tourism incomes.

\section{Acknowledgements}

The authors wish to thank the administration of cultural heritage, handicrafts and tourism of Semnan province office for providing some parts of information and data used in this paper.

\section{References}

[1] M. Mowforth, I. Munt, "Tourism and Sustainability Development globalization and new tourism in the Third World”, 3rd Ed, Routledge. Taylor \& Francis Group. London \& New York, 2009. p.6.

[2] I. Ebrahimzadeh, A. Aqhasizadeh, "Analysis of factors affecting tourism development in the coastal zone of Chabahar using SWOT strategy", Urban and Regional Studies and Research Journal, 1st year. 1st issue. Isfahan University, 2009. pp. 107-128.

[3] UNWTO News, "UNWTO World Tourism Barometer". Issue 25, PR No.: PR14004. Madrid, 2014.

[4] World Tourism Organization (UNWTO), "International tourism - a key to development. Prosperity and well-being", 2010. p. 2.

[5] A. Movahed, "The spatial distribution centers of residence in the historical cities, case study: Isfahan”, Research Human Geography, No. 65, 2008. pp. 105-116.

[6] E. Inskeep, "Tourism planning: an integrated and sustainable approach”, John Wiley \& Sons. New York, 1991. p. 119.

[7] A. Rezvani, "Geography and Tourism", University of PNU. Tehran, 1995. p. 8.

[8] A.M. Farajzadeh et al., "Evaluation and site selection urban educational centers Using Geographic Information System (GIS), case study: Moalem Zone in Kermanshah", Madras Journal of the Humanities, Vol. 8. No. 1, 2004. p.163.

[9] S. Christodoulakis et al., "A modular Approach to Support GIS Functionality in Tourism Applications", Laboratory of Distributed Multimedia Information Systems \& Applications - Technical University of Crete, 1998. p.1.

[10] R.M. Feng, A.M. Morrison, "GIS Application in tourism and hospitality marketing: A case in Brown County", Indiana. 13(2), 2003. pp.127-143

[11] B. Keshvari, P. Teimoori, "The Use of GIS and TIS in Feasibility Study of Tourism in Coastal, Case Study: City of Babolsar”, Journal of Human Geography, Year 2. No. 4, 2011. p.74.

[12] I. Ebrahimzadeh, M. Zeiaei and A. Delshad, "Strategic Planning and Development of Tourism", Desert Publishing. Mashhad. 1st Edition, 2012. p.62.

[13] H.R. Varesi, M. Taghvaei and A. Shahivandi, "An Analysis of Status of Tourism Infrastructures in Isfahan (With Emphasis Putting on Hotels)", Geography and Environmental Planning Journal, Year 22. Vol. 44. No.4, 2012. p.97.

[14] F.H. Zamani, "Iran Tourism and Travel Agencies", Zohd Press, 2001. p.200.

[15] Christopher M. Law, "Urban Tourism: Attracting Visitors to Large Cities", Mansell Publisher, London, 1996. pp. 109-110. 
[16] D.J. Timothy, G. Wall, "Tourist accommodation in an Asian-historic city", The Journal of Tourism Studies. Vol. 6. No 2, 1995. pp. 64-65.

[17] G.J. Ashworth, J.E. Tunbridge, "The Tourist-Historic City", London. Belhaven, 1990.

[18] Elisseeff Vadime, "The Silk Roads: Highways of Culture and Commerce", UNESCO Publishing, Berghahn Books. ISBN978-92-3-103652-1, 2001.

[19] Jerry Bentley, "Old World Encounters: Cross-Cultural Contacts and Exchanges in Pre-Modern Times", Oxford University Press, New York, 1993.
[20] Site of Silk Road Festival: http://silkroadfestival.blogfa.com/post-11.aspx

[21] Semnan Governorship, "Report of social-economic of Semnan province in 2007", the office of Planning and Budget. Planning Department of Semnan Governorship, 2008. pp. 697-698.

[22] Administration of Cultural Heritage, Handicrafts and Tourism of Semnan province, "Report 2; Evaluation and assessment of the tourism sector", Semnan province's tourism master plan, 2010. pp. 6-11. 